\title{
UGANDA: A Country Profile
}

\author{
Ahmad Masum
}

\section{Introduction}

Uganda lies in the heart of Sub-Saharan Africa. It is situated in East Africa and occupies an area of $241,038 \mathrm{sq} \mathrm{km}$ (roughly twice the size of the state of Pennsylvania) and its population is about 35,873,253 (CIA World Factbook, 2012). Uganda is bordered by Tanzania and Rwanda to the south, Democratic Republic of Congo to the west, South Sudan to the north, and Kenya to the east. Uganda is a landlocked country and occupies most of the Lake Victoria Basin, which was formed by the geological shifts that created the Rift Valley during the Pleistocene era. Uganda was a British colony and became an independent- sovereign nation in 1962 without a bloody struggle. Several ethnic groups reside in the country i.e. Baganda, Banyankole, Bahima, Bakiga, Bunyoro, Batoro, Basoga, Bagisu, Langi, Acholi, Lugbara, Karamojong and others. English is the official language by virtue of Article 6(1) of the 1995 Constitution and Swahili is also widely spoken especially in the urban areas. Uganda has no State religion. As a country, Uganda has witnessed some positive development in the area of security. The government managed to plant the seeds of peace in the north by defeating the Lord Resistance Army (LRA) led by Joseph Kony.

\section{History}

The history of Uganda cannot be understood and appreciated without making a cross reference to the colonial period. The first Europeans to visit Uganda were the British explorers John Hanning Speke and James Grant, when they were searching for the source of River Nile in 1862. They were followed by Samuel Baker and Charles George Gordon, commanding Egyptian troops. The explorer Henry Morton Stanley, welcomed by Kabaka (King) Mutesa (reigned 1852- 1884), reported the king's eagerness to understand Christianity. Soon both Protestant and Roman Catholic missionaries were working in Buganda (one of the four Kingdoms) in existence prior to the colonial history (Mutibwa, 1992, p.1).

Within a decade the factions they created caused a civil war. Once isolated, the region, with its rich soils, had become by 1890 a major object of the European nations' scramble for African territory. Britain, after securing German recognition of its rights, moved to secure Buganda. In 1894 the British government declared a protectorate over Buganda. Frederick Lugard, working with the East African Company, ended the civil disturbances, and his successors used the Bagandan army to help conquer the other kingdoms and tribes. By 1896 a British protectorate administration had extended its authority over most of the region, and the name Uganda was adopted. Final details concerning the administration of 
Uganda were to be settled by a series of agreements in 1966, the most comprehensive of which guaranteed special status to Buganda, including the continuation of its social and political system(Mutibwa, 1992, p.3). It is of paramount importance to note that Britain's almost 70 years of rule in Uganda was a centralized European bureaucracy superimposed on a federation of kingdoms and tribes. This worked relatively well until the independence movements of the 1960's, when Buganda demanded separation from Uganda. Only after Kabaka (King) Mutesa II was exited for two years in 1953 was it possible to proceed with developing a united government. After much experimentation, a federal constitution was promulgated in April 1962. The Uganda People's Congress (UPC) won the elections, and Milton Obote became the prime minister and Mutesa, King of Buganda the president. Independence was granted in October. Dissensions continued, however, and in May 1966 Obote sent the army into Buganda and drove the kabaka (king) into exile. It would appear that Milton Obote had no intention of sharing power with the president. He then proclaimed a new republican constitution, which formerly abolished the kingships, and became Uganda's first president of a unitary government (Mutibwa, 1992, p.43).

Bugandan recalcitrance, a fall-off in the economy, and charges of corruption led to an army coup in January 1971 when Milton Obote was in Singapore attending a Commonwealth meeting. Power devolved upon the army commander Idi Amin, who began eight years of terror and misrule. To the outside world, Idi Amin was portrayed as a 'sick man of Africa' who murdered his political opponents and also expelled more than 60,000 Asians, many of whom were entrepreneurs, from the country in 1972. It is said that Idi Amin gave the Asians 90 days to leave the country. They were forced to leave most of their property behind and it was shared among Idi Amin's cronies (Alcira, 2000, p.17). In order to distract attention from the terrible economic situation in Uganda, Idi Amin decided to invade Tanzania on 30 October 1978. However, the war turned into a disaster for Idi Amin. Early in 1979, the Tanzanians invaded Uganda and Idi Amin's forces fled.

After the fall of Idi Amin, three provincial presidents served before elections under a new constitution were held in December 1980. Obote's party won amid widespread reports of electoral fraud, and he became the president once again. Uganda, however, had changed fundamentally. Once thriving, the nation suffered prolonged economic disaster, with an inflation rate of more than 200 per cent, no consumer goods, few jobs, rampant crime, famine in the north, and no effective government in the countryside. In 1982, after Tanzanian troops had been withdrawn, anti-government guerillas became active, bloody internecine feuds (a legacy of the Amin period) flourished, and thousands of young men were arrested, suspected of being guerillas.

In July 1985 a coup overthrew the government; Obote fled the country and settled in Zambia. The National Resistance Army (NRA), led by Yoweri Museveni, formerly a Marxist, which had been fighting to overthrow Obote since 1981, continued the fight against the military regime which gusted him, and after four days of fighting in Kampala took over the country in January 1986. Among its first priorities was the re-building of a nation state from a 
country reduced after 15 years of misrule and violence into feuding factions. In his early years in office, Museveni to a certain extent restored peace in most parts of the country. With the assistance of large-scale foreign aid, efforts were made to rebuild the economy and infrastructure. Former Asian residents were invited to return, and a programme of economic liberalization introduced to bring the budget under control, encourage agricultural production, and attract foreign investors. During 1993 and 1994 debate began on a new constitution, as the first stage in a process of returning the country to a democratic government. The constitution, which allows for a referendum in 2000 on the future of a multi-party system, came into force in 1995. It is important to note that when Musevani first came to power he suspended political parties. In the 1996 presidential election Museveni was returned to power, having won 74 per cent of the popular vote (Uganda- History \& Politics, 2003). Although Museveni may be glorified by some of his party members, the truth is that the 2005 constitutional amendment lifting the presidential term limits has created more harm than good to the president. This has caused agitation, even in the party.

\section{Political System}

Uganda is a presidential republic, in which the President of Uganda is both head of state and head of government. The 1995 Constitution provides for an executive president, to be elected every 5 years. Executive power is exercised by the government. President Yoweri Museveni, in power since 1986, was elected in 1996 and re-elected in 2001, 2006, and 2011. Although Museveni was expected to step down after completing his two terms as provided under the 1995 Constitution, this never happened. In 2005, Parliament voted to remove term limits from the Constitution, giving Museveni a lifeline to continue as president. Legislative responsibility is vested in the Parliament; legislative elections are held every 5 years. The system is based on democratic parliamentary system with universal suffrage for all citizens over 18 years of age. The Ugandan judiciary operates as an independent branch of government and consists of Magistrate's Court, High Courts, Courts of Appeal (which also function as Constitutional Courts), and the Supreme Court. Parliament and the judiciary are independent bodies and wield significant power (CIA World Factbook, 2012)

Uganda had a history of the existence of political parties' right before independence i.e. the Uganda People's Congress (UPC) was founded in 1959 and the Democratic Party (DP) was founded in 1953. However, in a measure ostensibly designed to reduce sectarian violence, political parties were restricted in their activities from 1986. In the non-party "Movement" system instituted by the current president Yoweri Museveni, political parties continued to exist but could not campaign in elections or field candidates directly (although electoral candidates could belong to political parties). A constitutional referendum cancelled this 19year ban on multi-party politics in July 2005. Thus, it would suffice to note that the current political system in Uganda is that of a multi-party system. In February 2006, the country held its first multi-party general elections since 1980. Ruling National Resistance Movement (NRM) candidate President Museveni was declared the winner with 59\% of the vote, giving him a third term in office. Opposition Forum for a Democratic Change (FDC) leader Kizza 
Besigye captured $37 \%$ of the vote, while the remaining contestants received less than $2 \%$ of the vote each, according to official figures from the Electoral Commission. Besigye challenged the results in the Uganda's Supreme Court, which ruled that serious irregularities had occurred but were not significant enough to alter the outcome of the elections. On February 18, 2011, Uganda held its fourth presidential and parliamentary elections since Museveni came to power. Seven opposition presidential candidates, including FDC leader Kizza Besigye (the Inter-Party Cooperation candidate) ran against Museveni. On February 20, the Electoral Commission declared Museveni the winner with 68\% of the vote; Kizza Besigye came in second with $26 \%$ of the vote (US Department of State- Diplomacy in Action- Background Note: Uganda, 2012).

\section{Foreign Relations}

Foreign relations are very important area for the Uganda government. Uganda is a landlocked country, and foreign imports are crucial to Uganda. Mainly, consumer goods and energy equipments are the main needs of Uganda, which it imports from foreign countries. In Uganda, foreign relations have not always been very good with other countries mainly due to history of war and rebellion. The present regime, led by President Museveni, has put into place a new and radical foreign policies aimed at overall improvement of the International Relations of Uganda. This regime had on its agenda the forging of new relations especially with fellow African countries, and the opening of new trade routes. Though undermined by its reputation of the war, rebellions and clash of ideologies, the new regime has been successful in covering new grounds for the betterment of the International Relations of Uganda. The administration and management of Uganda's foreign policy is designed around three main areas; peace and security, regional cooperation and trade, tourism, investment and resource mobilization. In the foreign front, Uganda has played a major role in the area of peace and security within the region. For example, Uganda contributed to efforts to stabilize Somalia by providing troops for the African Mission (AMISOM) under the auspices of the African Union (AU). With durable peace in Somalia, proliferation of small arms in the region will be greatly curtailed.

\section{United Kingdom}

By virtue of its former imperial relationship with Uganda, Britain had special economic and political links with its former territory, although these connections eroded over the quarter century of upheaval after Uganda's independence. As British officials struggled to maintain ties, they chose to support Idi Amin and second Milton Obote regimes long after most Ugandans and most other foreign governments had rejected them. Relations with Britain also depended on the attitude of different Ugandan governments, which balanced their need for loans and technical assistance against their desire to project an image of a nonaligned foreign policy. At independence Britain had been Uganda's chief trading partner and the Queen its head of state. Irritated by President Obote's "move to the left" in the 1960s and by his vocal criticism of British arms sales to South Africa, the British government was 
delighted when Amin overthrew Obote in January 1971. Britain was the first country to recognize the new Ugandan regime and within few months provided Amin with military assistance. However, relations were strained to the breaking point in 1972 when without consultation or warning, Amin expelled Uganda's Indian population (about half of whom held British passports), forcing Britain to accept a large number of refugees despite its own restrictive immigration legislation (Yadav, 2008, p.148). Britain responded by halting all aid to Uganda and imposing an economic embargo. In January 1973, Amin recalled his high commissioner from London, nationalized British tea estates and other firms (but not British banks) and threatened to expel the 7,000 British residents of Uganda. By March the following year, 6,000 British had left Uganda, and Britain broke diplomatic relations in July 1976 when Amin's soldiers killed a woman hostage holding British and Israeli citizenship in revenge for the Israeli rescue of the other hostages captured by the Palestinians and held at the airport at Entebbe. Nevertheless, despite the revelations of atrocities carried out by state officials, the British government allowed private firms to supply Amin with luxury goods paid for with Ugandan coffee until 1979.

Immediately after the Amin regime was overthrown, Britain recognized the interim government and promised aid and technical assistance. Later in the interim period, the British government sent a team to train the police, a controversial initiative which it has continued ever since. British authorities responded cautiously to Obote's claimed success in the 1980 elections, but he convinced them of his pro-Western economic policies, they supported him to the bitter end. Then in 1986, despite their former support for Obote, the British immediately established close relations with the NRM. In November 1987, Museveni visited London, where he held talks with the queen and the prime minister, but at the same time, he continued to criticize their government for its failure to impose trade sanctions on South Africa. Today, Britain has a strong bilateral relationship and a significant development partnership with Uganda. Britain is committed to a dynamic and mutually beneficial relationship with Uganda. For example, the Department for International Development (DFID) is one of the largest bilateral donors to Uganda. DFID will spend an average of $£ 98$ million per year in Uganda until 2015. Furthermore, the promotion of human rights and democracy is also one of the cornerstones of the UKUganda foreign policy, and as such, the UK regards the respect for human rights as a priority. The British High Commission together with other UK government departments in Uganda strive to further: the right to equality before the law; the right to freedom from torture; the right to freedom of opinion and expression; the right to freedom of thought, conscience and religion; and the right to take part in the government of one's own country. The British High Commission provides support to international institutions based in the region such as the United Nations (UN) and International Organization for Migration (IOM). Together with the members of the European Union in Uganda, the Ugandan government, and other development partners, resources are shared with the mutual goal of upholding of the universal principles of human rights. 


\section{United States of America}

The United States (US) has had no significant geopolitical, business, or trading interests in Uganda, although a number of US firms did a profitable business with Uganda, particularly during the Amin period. For the most part, the US government has maintained a low profile, avoiding involvement in domestic Ugandan political issues, while administering a relatively small economic assistance program and seeking Uganda's support on several issues before the UN. For their part, the Ugandan authorities attempted to adhere to a policy of nonalignment that allowed them to criticize such US policies as its intervention in Vietnam, while persuading the US to expand its development assistance and to support an increase in Uganda's international coffee quota. After Uganda's break with Britain in 1973, the US became Uganda's chief trading partner for a short time, but relations were nonetheless becoming strained. The US Embassy was closed in November 1973 (although the Ugandan Embassy in Washington remained open), while the US firms supplied the government with security equipments used by the army and the notorious Ugandan intelligence service. In October 1978, the US Congress ended all trade with Uganda. With Amin's overthrow in 1979, the US Embassy reopened and provided emergency relief, particularly food, medical supplies, and small farm implements. When the second Obote regime indicated its pro-Western stance in 1980, the US government responded with additional agricultural assistance.

The guerilla struggle soon created new strains between the US and Uganda, however, as the US Embassy forthrightly reported to its Congress the pattern of growing human rights violations by the government and army officials. When the NRM came to power, friendly relations were quickly restored. The US aid program was reoriented to focus on immediate rehabilitation priorities identified by the Ugandan government, particularly the war-damaged areas in the Luwero Triangle and in the matter of the resettlement of refugees returning from Sudan and Democratic Republic of Congo (formerly known as Zaire). Museveni visited Washington in October 1987 and February 1989 for consultations with the president and members of the Congress. The relationship between US and Uganda under the regime of Museveni could be viewed as a positive one in many aspects. The US has been working together with the Uganda toward an aids- free generation. Since 2004, the American people have invested over $\$ 1.7$ billion in support of the national Human Immunodeficiency Virus (HIV) response in Uganda. Working with the Government of Uganda, civil society, community and faith-based groups, and other donors, the US President's Emergency Plan for AIDS Relief (PEPFAR) has made a major contribution to saving lives. Furthermore, the US government has taken extraordinary steps to curb the spread of Malaria in Uganda with the help of the World Bank Booster Program for Malaria Control and the Bill and Melinda Gates Foundation. The US President's Malaria Initiative (PMI), led by the United States Agency for International Development (USAID) and implemented jointly with US Centers for Disease Control and Prevention (CDC), is working in 19 focus countries in Africa, and the Greater Mekong Sub-region ((US Department of State- Diplomacy in ActionBackground Note: Uganda, 2012). 


\section{European Union}

The European Commission (EC) - Uganda co-operation began with the 1968 Arusha Agreement, inaugurating formal relations between the European Community and the former East African Community states. As a signatory to the first Lome Convention in 1975, Uganda joined the African, Caribbean and Pacific group of countries and an EC delegation was established in Kampala the following year, in 1976. Uganda has since then participated in Lome II, III and IV conventions and is now part of the Cotonou Agreement signed on June 23, 2000. The European Union (EU) political dialogue with Uganda under the Cotonou agreement covers socio-economic transformation, regional peace and security issues, transparency, human rights, and the democratic process. Perhaps it is important to note that as an economic force, the EU is the largest source of direct foreign investment in the world as well as the largest trading partner with countries in the Sub-Saharan Africa, including the East African countries. The EU currently has excellent relations with Uganda and intense political dialogue at all levels, including with President Museveni. The EUUganda economies are linked through extensive trade and other business-to-business relationships. EU is Uganda's biggest trading partner. The EU market consumes about 55\% of Uganda's total exports. The EU is the largest market for non-traditional exports such as fish, flowers, fresh fruits and vegetables. Like other developing countries, Uganda is a beneficiary of unlimited duty-free and quota-free access to the EU market.

\section{Commonwealth}

Uganda became a member of the Commonwealth in 1962. As a member state, Ugandan has hosted Commonwealth meetings such as the 2007 Eighth Commonwealth Women's Affairs Ministers Meeting in Kampala. In the same year, Uganda hosted the Commonwealth Heads of Government Meeting (CHOGM) resulting in the Kampala Declaration on Transformation Societies to Achieve Political, Economic and Human Development; the Lake Victoria Commonwealth Climate Change Action Plan; and the Munyonyo Statement on Respect and Understanding. Overall Uganda as a family of the Commonwealth community has played and continues to play a significant role.The Commonwealth Secretariat has been working with Uganda in building technical and managerial ability of individuals, systems and processes in public institutions to help them continuously improve their performance; strengthening public service training institutes to close gaps in the skills of people working in public services; and developing the effective use of information and communication technology strategies in the public sector.

\section{China, Japan, India and Malaysia}

Uganda has benefited from relations with some countries in Asia such as China, Japan, India and Malaysia. For instance, China and Uganda established trade relations in 1960. In 2005, the trade volume between the two countries came to US\$99.37 million, among which China's export was US\$79.37 million, and import US\$20 million (Uganda Bureau of 
Statistics, 2006). China's main exports to Uganda are mechanical and electrical appliances, textiles, garments, pharmaceuticals, porcelain and enamel products, and footwear. China's imports from Uganda are coffee and plastics. The economic and trade cooperation between China and Uganda has become more and more diversified. Based on the good foundation, China is to take further measures to increase the import of Ugandan products. Furthermore, China and Uganda have carried out various kinds of cultural exchange and cooperation since the establishment of diplomatic relations. The two countries signed a cultural cooperation agreement in June 1985. In August 199, China and Uganda signed the 20002002 Implementation Program of the Agreement on the Cultural Cooperation between China and Uganda. Today, there are several Ugandan students studying in China. The relations between China and Uganda have involved a wide array of stakeholders. Each of these categories act in the best interests of the economy they represent. In the public and private sector, the Uganda Investment Authority (UIA) is the governing body whose main role is to offer investment opportunities and facilitation and after care for both local and foreign investors. In addition, UIA identifies and markets Uganda's competitive advantage in order to attract investment in priority sectors and they also identify priority sources (countries) of investment. In the aid department, the Government of Uganda through the Ministry of Finance, Planning and Economic Development (MFPED) sources and manage aid inflows from China. The Ministry of Health (MOH) helps in outsourcing the best medical services like brain surgeons, heart surgeons and other critical disease experts and equipments from China (Obwona et al., 2007, pp.2-3).

Japan and Uganda have been enjoying very cordial relations for the last 50 years. Japan has supported Uganda with $\$ 1$ billion in the last five years funding many programmes in various sectors including health, agriculture, electricity, road construction and education among others. For example, Japan has increased its Official Development Assistance (ODA) Grant funding for important projects such as Kampala road network, health sector, education and agro processing. Japan's financial support to emergency relief towards northern Uganda, mainly through the United Nations Children's Fund (UNICEF) and the World Food Programme (WFP) was quite substantial. Japan also undertook to double its ODA to Africa between 2005 and 2008. Japan International Cooperation Agency (JICA) technical assistance in capacity building to Uganda is quite encouraging ever since they opened an office in Kampala. JICA activities range from education, agricultural/rural development and peace building. Under the rural development scheme, the JICA has managed to introduce a successful sustainable irrigated agricultural development project in Eastern Uganda (Ministry of Foreign Affairs of Japan).

Uganda's relationship with India suffered most notably in 1972 when Idi Amin expelled them from the country. In late 1980s, Indian nationals started returning to Uganda and repossessing most of the properties they had lost at expulsion. The volume of trade between India and Uganda has increased. Between 1984 and 2003, the volume rose from \$5.6 million to $\$ 105.5$ million (The New Vision, 2007). In subsequence, India's exports to Uganda, have also increased. India is now the second biggest exporter to Uganda (after Kenya). Exports 
constitute around $8.5 \%$ of Uganda's total imports. Major exports items are: pharmaceuticals, bicycles and bicycle parts, automobile components, tyres, small industry and agro-processing machinery etc. The economic relations between India and Uganda have been on the upswing with more and more Indian companies starting their new business ventures in Uganda. By the end of 2003, India was ranked the largest investor in Uganda, information provided the Uganda Investment Authority, lists the Indian investors as Tata Group of Companies, Roadmaster Cycles, Mahindra Tractors and Applied Pavement Technology (APTEC) all of which have registered local companies in Uganda (The New Vision, 2007).

Malaysia and Uganda do not share a strong economic tie. However, both countries are now working very hard to strengthen trade relationship. Malaysia, the largest palm oil producing country in the world is seeking an opportunity to export its palm oil and related products to Uganda as it moves to strengthen its market position. With over 4.8 million hectares of palm oil, Malaysia produces over 17 million tonnes of palm oil products and earns $\$ 20$ billion in export earnings (The Monitor, 2011). Other big producers of palm oil and its products include Indonesia, Argentina and Brazil. Palm oil yields a number of products, including vegetable oil, chocolates, soaps, vaseline and vegetable ghee, among others. Currently, Bidco with an 8,000-hectre palm oil plantation in Kalangala is the largest palm oil producer in Uganda. If Malaysia begins exporting its palm oil and related products to Uganda, this would mean increased competition which might in turn benefit consumers through reduced prices. It is also important to note that Malaysia currently offers scholarships, technical assistance in capacity building and Small and Medium-Size Enterprise (SMEs) development programmes to Uganda.

\section{The African Union}

Uganda has worked very closely with the African Union (AU) in achieving the vision and mission of this auspicious body in the continent. For example, Uganda contributed to efforts to stabilize Somalia by providing troops for the African Mission (AMISOM) under the auspices of the AU. With durable peace in Somalia, proliferation of small arms in the region will be greatly curtailed. Uganda also played a major role in the regional initiative for peace in Burundi by chairing this initiative that led to the conclusion and signing of the Arusha Peace and Reconciliation Agreement. Furthermore, Uganda played an active role in the conflict in the Democratic Republic of Congo (DRC) from 1996 and was one of the five signatories to the 1999 Lusaka Cease-fire Agreement. Under the terms of the 2002 Luanda Agreement between Uganda and DRC, Uganda completed the withdrawal of its troops in June 2003.The contributions of Uganda to the AU cannot be underestimated as far as maintaining peace and security in the continent is concerned.

\section{Administrative Set-up}

In Uganda, the administrative set-up is made up of the Central Government and the Local Governments. Presently, the country has one hundred twelve districts and one city 
(Kampala) across four administrative regions. These four administrative regions are: the central region, the eastern region, the western region, and the northern region. The Central Government is responsible for national affairs and services; formulation of national policies and national standards and monitoring the implementation of national policies and services to ensure compliance with standards and regulations. As to the system of Local Government, it is based on the District as a Unit which there are lower Local Governments and Administrative Unit Councils. Elected Local Government Councils which are accountable to the people are made up of persons directly elected to represent electoral areas, persons with disabilities, the youth and women councilors forming one third of the council. The Local Government Council is the highest political authority in its area of jurisdiction. The councils are corporate bodies having both legislative and executive powers. They have powers to make local laws and enforce implementation. On the other hand, Administrative Unit Councils serve as political units to advise on planning and implementation of services. They assist in the resolution of disputes, monitor the delivery of services and assist in the maintenance of law, order and security. The Local Governments in a District rural area are: the District and the Sub-county. The Local Governments in a city are: the City Council and the City Division Council. The Local Governments in a Municipality are: the Municipal Council and the Municipal Division Council. The Administrative Units in the rural areas are: County, Parish and Village. The Administrative Units in the urban areas are: Parish or Ward and Village. It is important to note that the Local Government Act, 1997 gives effect to the devolution of functions, powers, and services to all levels of Local Government to enhance good governance and democratic participation in and control of decision-making by the people. The law also provides revenue, political and administrative setup of Local Governments as well as election of Local Councils. The powers which are assigned to the Local Governments include powers of making local policy and regulating the delivery services; formulation of development plans based on locally determined priorities; receive; raise, manage and allocate revenue through approval and execution of own budgets; alter or create new boundaries; appoint statutory commissions, board and committees for personnel, land, procurement and accountability; as well as establish or abolish in Public Service of a District or Urban Council (Kisembo, 2006, pp.1-12). Perhaps in addressing the administrative set-up of Uganda, it is equally important to make a reference to the restoration of traditional leaders or cultural leaders in 1993. A traditional leader or cultural leader shall not have to exercise any administrative, legislative or executive powers of Government or Local Government. Furthermore, while remaining a traditional leader or a cultural leader, he shall not join or participate in partisan politics. This is all by virtue of Article 246 of the Constitution of the Republic of Uganda (i.e. the 1995 constitution). It should be noted that some of these traditional leaders or cultural leaders have demanded for a federal type of administration (federalism).

\section{Economy}

Uganda has substantial natural resources, including fertile soils, regular rainfall, small deposits of copper, gold, and other minerals, and recently discovered oil. Uganda has 
never conducted a national minerals survey. Agriculture is the most important sector of the economy, employing over $80 \%$ of the work force. Since 1986 , the government with the support of foreign countries and international agencies has acted to rehabilitate and stabilize the economy by undertaking currency reform, raising producer prices on export crops, increasing prices of petroleum products, improving civil service wages. The policy changes are especially aimed at dampening inflation and boosting production and export earnings. Since 1990 economic reforms ushered in an era of solid economic growth based on continued investment in infrastructure, improved incentives for production and exports, lower inflation, better domestic security, and the return of exiled Indian-Ugandan entrepreneurs (Kuteesa et al., 2009, pp.27-30). Recognizing the need for increased external support, Uganda negotiated a policy framework paper with the International Monetary Fund (IMF) and the World Bank in 1987. It subsequently began implementing economic policies that resulted in a consistent pace of economic growth. Uganda was the first country to be eligible for the Heavily Indebted Poor Countries (HIPC) initiative and had virtually all of its debts forgiven by IMF, World Bank, and major donors (US Department of State Diplomacy in Action, 2012). Coffee accounts for the bulk of export revenues. Uganda has received about $\$ 2$ billion in multilateral and bilateral debt relief. In 2007, Uganda received \$10 million for a Millennium Challenge Account Threshold Program. The global economic downturn has hurt Uganda's exports; however, Uganda's Gross Domestic Product (GDP) growth is still relatively strong due to past reforms and sound management of the downturn. Oil revenues and taxes will become a large source of government funding as oil comes on line in the next few years (CIA World Factbook, 2012). Under the leadership of Museveni, Uganda has seen some of the most far-reaching political and economic changes in the country, beginning in 1987 with the launch of an economic reform programme supported by the World Bank and IMF (Bigsten \& Mugerwa, 2001, p.14).

\section{Uganda at Glance}

Capital city: Kampala

Nationality:Noun and adjective- Ugandan(s)

Type of government: Republic

Independence: 9 October 1962 (from the UK)

National holiday: Independence Day, 9 October (1962)

Population: 35,873,253 (July 2012 est.)

Population growth rate: $3.582 \%$ (2011 est.)

Approximate size: $241,038 \mathrm{sq} \mathrm{km}$ (roughly twice the size of the state of Pennsylvania)

Life expectancy at birth: Male: 52.4 years; Female: 54.54 years (2011 est.)

Ethnic groups: Baganda 16.9\%, Banyakole and Bahima 9.5\%, Basoga 8.4\%, Bakiga 6.9\%, Iteso 6.4\%, Langi 6.1\%, Bagisu 4.6\%, Lugbara 4.2\%, Bunyoro $2.7 \%$, other $29.6 \%$

Religions: Catholic 41.9\%, Protestant 42\%, Muslim 12.1\%, other 3.1\%, none $0.9 \%$ (2002 census)

Languages: English (official), Swahili, Ganda or Luganda, and numerous other local languages 
Literacy:Total Population: $66.8 \%$; Male: $76.8 \%$; Female: $57.7 \%$

GDP- real growth rate: $6.4 \%$ (2011 est.)

GDP- per capita: $\$ 1,300$ (2011 est.)

HIV/AIDS- adult prevalence rate: 6.5\% (adult, aged 15-49) (2009 est.)

Unemployment rate: NA\%

Administrative divisions: 112 districts and 1 city (Kampala) across 4 administrative regions

Major political parties and leaders: Conservative Party or CP [Ken LUKYAMUZI]; Democratic Party or DP [Nobert MAO]; Forum for Democratic Change or FDC [Kizza BESIGYE]; Inter-Party Co-operation or IPC (a coalition of opposition groups); Justice Forum or JEEMA [Asuman BASALIRWA]; National Resistance Movement or NRM [Yoweri MUSEVENI]; Peoples Progressive Party or PPP [Bidandi SSALI]; Uganda People's Congress or UPC [Olara OTUNNU]

Sources. CIA World Factbook; the World Bank; Economist Intelligence Unit

\section{References}

Bigsten, A., \& Mugerwa, S. K. (2001). Is Uganda an emerging economy? A report for the OECD project emerging Africa. Uppsala: Nordic African Institute.

British High Commission Kampala- Working with Uganda. (2012, July 2). Retrieved from http://ukinuganda.fco.gov.uk/en/about-us/working-with-uganda/

CIA World Factbook. (2012). Retrieved from https://www.cia.gov/library/publications/theworld-factbook/geos/ug.html

Kisembo, S.W. (2006). Handbook on decentralisation in Uganda. Uganda: Fountain Publishers.

Kreimer, A. (2000). Uganda: Post conflict reconstruction country case evaluation. Washington: World Bank.

Kulabako, F. (2011, June 17). Malaysian palm oil makers seek market in nation. The Monitor. Retrieved from http://www.accessmylibrary.com/article-1G1-259149688/ malaysian-palm-oil-makers.html

Kuteesa, F., Mutebile, E.T., Whitworth, A., \& Williamson, T. (Eds.). (2009). Uganda's economic reforms: Insider accounts. Oxford: Oxford University Press.

Ministry of Foreign Affairs of Japan- Japan-Uganda Relations. (2010, May). Retrieved from http://www.mofa.go.jp/region/africa/uganda/index.html 
Mutibwa, P. (1992). Uganda since independence: A Story of unfulfilled hopes. New Jersey: Africa World Press.

Nsambu, J. M. (2007, November 17). India- Uganda trade grows. The New Vision. Retrieved from http://www.enteruganda.com/brochures/indiauganda.html

Nsambu, J. M. (2007, November 19). India, Uganda maintain ties. The New Vision. Retrieved from http://www.enteruganda.com/brochures/indiaties5.html

Obwona, Guloba, Nabiddo., \& Kilimani. (2007). China-Africa economic relations: The case of Uganda. Kampala: Economic Policy Research Centre.

Uganda- History and Politics (2003, January). Retrieved from http://www.iss.co.za/Af/ profiles/Uganda/Politics.html

US Department of State Diplomacy in Action Background Note: Uganda. (2012, April 6). Retrieved from http://www.state.gov/r/pa/ei/bgn/2963.html

US Department of State- Diplomacy in Action- Background Note: Uganda. (2012, April 6). Retrieved from http://www.state.gov/r/pa/ei/bgn/2963.html

Yadav, S.N. (2008). India-Uganda Relations: A new model for south-south cooperation. New Delhi: Global Vision Publishing House. 
